\begin{abstract}
Iranica
Abstracta Iranica Revue bibliographique pour le domaine irano-aryen

Volume 37-38-39 | 2018

Comptes rendus des publications de 2014-2016
\end{abstract}

\title{
Kaori O'Connor. The Never-Ending Feast: The Anthropology and Archaeology of Feasting
}

\section{Astrid Nunn}

\section{(2) OpenEdition}

\section{Journals}

Édition électronique

URL : http://journals.openedition.org/abstractairanica/44069

DOI : 10.4000/abstractairanica.44069

ISBN : 1961-960X

ISSN : 1961-960X

Éditeur :

CNRS (UMR 7528 Mondes iraniens et indiens), Éditions de l'IFRI

Référence électronique

Astrid Nunn, « Kaori O'Connor. The Never-Ending Feast: The Anthropology and Archaeology of Feasting », Abstracta Iranica [En ligne], Volume 37-38-39 | 2018, document 2, mis en ligne le 30 décembre 2018, consulté le 27 septembre 2020. URL : http://journals.openedition.org/abstractairanica/44069 ; DOI : https://doi.org/10.4000/abstractairanica.44069

Ce document a été généré automatiquement le 27 septembre 2020.

Tous droits réservés 


\title{
Kaori O'Connor. The Never-Ending Feast: The Anthropology and Archaeology of Feasting
}

\author{
Astrid Nunn
}

\section{RÉFÉRENCE}

Kaori O'Connor. The Never-Ending Feast: The Anthropology and Archaeology of Feasting. London, New York : Bloomsbury Academic, 2015, 256 p., 21 ill.

Constatant que le banquet est une institution culturelle mondialement répandue, l'A. passe en revue son histoire en Grèce antique, au Proche Orient ancien (Mésopotamie, Assyriens, Achéménides), en Mongolie et en Extrême Orient (Chine et Japon) de 4000 av. J.-C. à 1600 ap. J.-C.

2 Le but de cette large synthèse est de consolider la base d'informations sur laquelle toute étude se fonde. Le banquet, que l'A. considère aussi à la lumière des théories de « consommation démonstrative» (conspicuous consommation) de T. Veblen, allie de nombreux aspects sociétaux (rites, pratiques) et religieux (mythes). Au Proche Orient ancien le banquet est un service rendu aux dieux, dont les hommes profitent en retour. Pour la Perse achéménide (p. 61-83) l'A. décrit la préparation rituelle de la plante encore non identifiée haoma ou soma, l'ordre des hôtes, la tenue du Grand Roi, les mets consommés ou encore la musique accompagnatrice. Sans apporter du nouveau ce chapitre est une bonne synthèse que le lecteur pourra d'autant mieux apprécier qu'elle est replacée dans un contexte historique très large. 


\section{AUTEURS}

\section{ASTRID NUNN}

Université de Munich 